\title{
Slavic Antiquities and Forgeries as Means for the Shaping of Canons*
}

\author{
RÓBERT KISS SZEMÁN \\ ELTE BTK Szláv Filológiai Tanszék, H-1088 Budapest, Múzeum krt. 4/D. \\ E-mail: kiss.szeman.robert@gmail.com
}

(Received: 24 April 2019; accepted: 27 June 2019)

\section{Slavic antiquities and antiquarians}

The purpose of the study which follows is to call attention to the phenomenon of the forging of antiquities, an organic part of the culture of national revivals. 'Antiquity' here is understood to mean a document, book, picture, coin or medal, sculpture, or other kind of medium that conveyed textual or visual information from before the 19th century. The collecting of antiquities became fashionable during the period in question, with the most famous antiquities collections, e.g. the Czartoryskis' collection in Poland and the Széchényis' collection in Hungary, later forming the basis for national museum collections. At the same time, collecting led to the need for antiquities to be described and categorized. In turn, antiquities thus processed served as corpuses for the shaping of modern national cultural canons.

One of the oldest Slavic antiquities is the Reims Gospel, also known as the Texte du Sacre ('coronation text'). According to the state of research today, it came into being in 1395 in the Emmaus Monastery in Prague (see PACNEROVA 1996) as a product of the revival of reading and writing in Glagolitic that took place in Bohemia during the time of Holy Roman Emperor Charles IV. This manuscript in Glagolitic was joined later on with a work in Cyrillic that was probably written in Kiev during the 12th century. It was in this form that the Gospel was taken to Reims in 1574. There, a number of kings of France took their coronation oath on it (HawryluK 2009), hence the name in French. At the time of the French Revolution, the Reims Gospel disappeared for a while (KolLÁR 1832: 495-496). Scholarly discourse regarding this Slavic antiquity began around the turn of the 19th century. One of the first protagonists in this was the Viennese antiquarian Franz Karl Alter (1749-1804).

The debates on the origins of the work were joined by Josef Dobrovský, who made reference to Johann Gottfried Eichhorn's series dealing with books of the Bible as additional source material in German (see EICHHORN 1800). The popularizing of Slavic antiquities was continued by A. L. Schlözer, too, in his edition of Nestor's Primary Chronicle, which was very highly regarded by scholars active

\footnotetext{
* This study was supported by a grant from the NKFI (K-124873).
} 
at that time: 'the Slavic Gospel on which the kings of France took their oath when they were crowned at Reims must have been particularly old: alas, it perished as a result of cannibalism at the start of the revolution' (SCHLÖZER 1802, KOLLÁR 1832: 495). In the 'Acheron' canto of his poem The Daughter of Sláva, Kollár consigned the sans-culottes and the Jacobins to perdition for destroying this esteemed Slavic antiquity (KOLLÁR 1852: 612); also, he made reference to each of the authors listed above in the explanation he wrote for the sonnet (Kollár 1832: 495).

This example has been chosen out of many because it serves well to point out numerous characteristic features of antiquities. Thus, an antiquity's canonical value stemmed from its age most of all (in the 18th-19th centuries, the Reims Gospel was linked not to Bohemia during the Middle Ages, but to the Old Slavonic period that preceded this time by many centuries). Also, an antiquity needed to be linked as specifically as possible, and exclusively, to the history and culture of a given nation or set of nations (in the present case, Cyrillic and Glagolitic as specifically Slavic ways of writing were likewise value-enhancing factors). The worth of an antiquity in the cultural canon was further boosted when it could be connected with historical personages of great significance (a succession of kings of France satisfied this particular expectation beyond all doubt). Finally, the more mysterious and romantic the history of an antiquity, the greater the degree of speculation permissible in regard to interpretations of it (the Reims Gospel met this requirement to the maximum degree since the circumstances of its genesis, those of its arrival in France's coronation city, and those of its disappearance during the French Revolution were all unclear).

The importance of antiquities is indicated by Kollár's devotion of a sonnet (no. 462) to them in his work The Daughter of Sláva, in the canto entitled 'Lethe' (which depicted the Slavic Paradise). In this sonnet, Kollár's presenting of the artefacts in the Hall of Slavic Antiquities can easily be seen as the first virtual Slavic museum exhibition. In the third stanza of the sonnet in question, collectors and scholars dealing with Slavic antiquities are listed. They include Zorian DolęngaChodakowski (1784-1825) (KolláR 1832: 346), whose work O Stawiańszczyźnie przed chrześcijaństwem ('The Slavs before their Christianization') was important in the science of the era; Miklós Jankovich (1773-1846), a scholar and author associated with the periodical Tudományos Gyüjtemény, whose 'inestimably valuable collection of antiquities, coins and medals' is mentioned by Kollár in his Explanations (Kollár 1832: 346); ${ }^{1}$ Andreas Gottlieb Masch (1724-1807), who will be discussed in more detail later; and Martin Friedrich Arendt (1773-1823), likened to Diogenes by Kollár, who mentioned Arendt's time in Budapest (Kollár 1832: 346-347) ${ }^{2}$ drawing attention to his work on the North Slavs (Kollár 1832: 347,

1 ‘...má neocenitelnau Sbjrku starotin a mincj wšeligakých, mezi nimi mnohé i ruské, polské, české, serbské, ze slawskými nápisy’.

2 'Byl w Italii, w Pařjži, we Spanielsku tjm cjlem. Gda po druhý kráte do Italie péšky, zderžowal se za čas i w Pešti, špatně oděný, knihy a rukopisy mezi tělem a košilj nose - spáwal nayčastěji pod křowinau, aneb stromem u poli, aneb byloli deštiwo, pod mostem; zemřel r. $1824 \mathrm{w}$ bljzkosti Benátek'. 
Legis 1829: 41). ${ }^{3}$ To this international company were connected other, Central European, antiquarians: the Czechs Josef Dobrovský and Josef Jungmann, the Hungarian István Horváth, the Slovene Jernej Kopitar, and, last but not least, Ján Kollár and Pavol Jozef Šafárik. It was thanks to the tenacious work of analysis and evaluation performed by these figures that every Central European nation was able to put together its own corpus of antiquities in the first decades of the 19th century. Rather fluid and even amorphous in this period, these canons not only laboured under the burden of serious inner gaps and tensions but also had constantly to confront similar constructs on the part of other nations. The inward (structural) tensions of the still-forming national canons and their outward confrontations (with other systems) provided the basis for most of the debates concerning antiquarianism. The shaping of canons is always a complicated process. It was no less so in the age of national revivals (GORAK 1991) since at this time, cultural canons were ideological signifiers for groups in society proclaiming the importance of nationality (ALTIERI 1983: 39). ${ }^{4}$ In these canons, forgeries also came to occupy a prominent place.

\section{Antiquity forgery and temporality}

In the hermeneutic sense, a forgery is an attack on the authentic; it is something which calls an entire system into question, thereby causing bewilderment. From this perplexity, only one person can derive benefit, namely, the forger. The forger is, therefore, someone in need of benefit because he or she is suffering a dearth of something. According to Sándor Radnóti, who investigated grounds for misrepresentation strategies, a forger's motive may be hope of material gain, a lack of success for his or her own substantive works, anger at the system of canon formation, or simply delight in playing the imposter (RADNóTI 1995: 31-54). A mix of these in the right proportions is clearly present in the motivations of forgers of Slavic antiquities, too, as shall be seen from the examples given later on. However, the above-mentioned cocktail of motives was supplemented around the turn of the 19th century by an element linkable to the cause of the modern nation: forgeries, the burgeoning spread of false information conveyed by them, and the incorporation of this information into the national cultural canons were organic components in the forming of modern nations.

Forgery as a technique for deception is as old as history itself. A forged antiquity is basically an objectification informed by the forger's thinking and imagination. By virtue of this, a forgery bears not just marks characteristic of past times but also those of the forger and the time in which the forgery was made (SZILÁGYI

\footnotetext{
3 'Grossherzoglich-Strelitzisches Georgicum [according to some sources, Georgium] Nord-Slawischer Gottheiten und ihres Dienstes; aus der Urbildern dargestellt von M. F. Ahrendt, Nordischer Alterthumsforscher aus Altona, Minden, 1820'; Legis makes reference to Arendt's work above by means of a footnote remark in which he expresses his thanks to Dobrovský for the book because Arendt's work could be purchased only personally from the author.

4 'Canons are simply ideological banners for social groups: social groups propose them as forms of self-definition...'
} 
2005: 167-175). This explains the circumstance that it is relatively easy for skilful forgers to deceive contemporaries given to enthusiastic acceptance of forgeries combining components of the past and present that seem relevant to them. A good illustration is the reception accorded by the Czechs to the Queen's Court Manuscript and the Green Mountain Manuscript. When they were published, in 1816 and 1817 respectively, these manuscripts appeared differently when seen from the standpoint of Enlightenment rationality on the one hand, and through the prism represented by the overheated historicizing occasioned by Romanticism on the other. For Dobrovský, who viewed them from the philosophical standpoint of the preceding, Enlightenment, era, both manuscripts were clearly forgeries. On the other horizon were representatives of the Romantic generation of the time who happily hailed the unexpected 'emergence' of the manuscripts from the mists of early medieval Czech history. Moving backwards on the time continuum, we see that the fake nature of the manuscripts in question was invisible to contemporaries. Moving forward on it again, to the final third of the 19th century, we observe that their bogus character is already clear to people, the result of debates around the manuscripts led by Masaryk. During the process of self-revelation, the authenticity of an element which undid the structure of the canon became questionable. This might be followed by the artefact's marginalization, by its sinking into oblivion, and possibly, as the reception of the above two manuscripts shows, by its finding of a new place in the cultural canon as a particular, substantive artwork of unknown authorship.

Important among the motives for the forging of Slavic antiquities was the circumstance that framers of canons felt that the structures of their national cultures were incomplete and wished to remedy this trauma whatever the cost. It follows from this that the forging of Slavic antiquities served to build up modern national cultures in the same way that many legitimate scientific and artistic means used in the first half of the 19th century served to build them up. After all this, a question arises: was the forging of Slavic antiquities something good and necessary? By way of reply, it may be said that while forgery, as an attack on the authentic, is traditionally and in general naturally bad, in relation to forgeries of antiquities and modern national canons a certain historical necessity for it can be shown retrospectively. To wit, in order for a structure to come into being, there is often a need for an inductive approach and for props. The necessity of forged antiquities in Central Europe may be illustrated using a metaphor from architecture, namely, that when vaulting is to be built, in most cases, centring is needed that can only be safely removed when the keystone is already in place. In what follows, four examples are given of overlapping aggregates of forgeries and antiquities that found their way into Slavic cultures or else came into being as products of Slavic cultures.

\subsection{The Poison Tree of Java}

According to Sándor Radnóti, one of the most common motivations for forgery is playing the imposter, with the aim of deceiving snobs and having a laugh at their expense (see RADNÓTI 1995: 31-54). By way of illustration and example, a case is 
presented which is drawn from another culture but which, because it fell on the overheated soil of Romantic fantasy, swept almost the whole of Europe, the Slavic cultures included. The wave was launched by an Englishman named George Steevens (1736-1800). In the December 1783 number of The London Magazine (pp. 513-517), Steevens published an account purportedly by a certain N. P. Foersch, a physician on a Dutch ship, of a journey he made to Batavia in 1774 that had been translated into English from the original Dutch by a 'Mr. Heydinger'; the actual author, Mr. Heydinger was Steevens himself (WACHTEL 2011: 109). In this work, Steevens told of a tree whose poisonous aroma destroyed every living creature in its vicinity. The phenomenon inspired English poets and painters firstly (cf. GusTAFSON 1960): Erasmus Darwin, who mentioned it in his poem The Loves of the Plants published in 1789 (Canto III, lines 219-258); William Blake, who made reference to it in his poem A Poison Tree included in the 1794 edition of his work Songs of Experience; Byron, who visualized it in Childe Harold (Canto IV, stanza 126); and Francis Danby, who belonged to the Romantic Bristol School and who in 1820 produced his painting The Upas Tree. The false report found its way into Slavic cultures as well. In Russian-language territories, it made its first appearance in 1787, in the children's periodical Detskoe chtenie dlya serdca i razuma, in issue no. 7 of that year; later, news of the tree featured in the periodical Muza, in issue no. 3 of 1796. Influenced by this, Pushkin wrote his poem Anchar ('The Upas Tree') in 1828 (Bogoljubova 1958). In connection with the Czechs and Slovaks, an account of the terrifying plant was given in the periodical Prvotiny pěkných umĕní, in the wake of which the poison tree found its way into the canto in Kollár's work The Daughter of Sláva that presented the Slavic Hell. This canto was written between the publication of the 1824 edition of the work and the 1832 edition, when

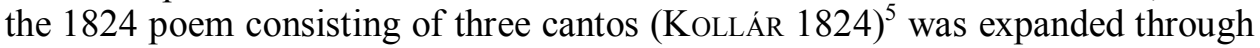
the addition of another two. In the most complete 1852 edition of The Daughter of Sláva, this sonnet bears the number 564. According to the lines and the explanation given for them, the Poison Tree was a metaphor for Timur Lenke and Asiatic despots. (It should also be noted that in the usage of the Slavic cultures in Central Europe at this time, the adjective Asiatic alluded to the Hungarians most of all.)

In the case of the Poison Tree of Java, our business, then, is with false information aimed primarily at the British reading public. The acceptance of these false facts recordable as merely a secondary impact in the Slavic cultures in Central and Eastern Europe is attributable to the wish for horror and awe found in Dark Romanticism (Praz 1963). The Poison Tree motif went out of fashion at the same time as Romanticism itself, namely, in the second half of the 19th century, and was eventually given its coup de grace by Positivism. Because of the erosion of Kollár's oeuvre, the motif lacked any subsequent reverberation in Czech and Slovak literature; at the same time, thanks to one of Pushkin's most famous poems, it is still part of the Russian cultural canon and world literature alike.

\footnotetext{
${ }^{5}$ The 'second edition' mentioned in the title is misleading; Kollár regarded his volume entitled Básně to be the first edition.
} 


\subsection{The Slavic idols of Prillwitz}

The next example, which likewise comes from the territory of a foreign culture, specifically from the town of Prillwitz in Germany, provides another form of Slavic appropriation of foreign forgery. Idols were found in this Mecklenburg town in the 1760s. The role assigned to these idols entered the modern cultural canon because they were linked to the prehistory or early medieval history of Slavic peoples before their Christianization and, as cultic artefacts, were meant to embody their uncorrupted national genius. The belief system and mythology of the pagan Slavic tribes in Germany had great seductive power. Their history was, thanks to early medieval chronicles, relatively well documented, while their languages and cultures were pretty much written up, thanks to German scholars in the modern age (Grosser 1714, MATTHÄI 1721, KöRNER 1766). It was no coincidence that Kollár admitted to the Slavic Heaven those German scholars who concerned themselves with Slavic antiquities and with the material and spiritual culture of Germany's Slavs (Kollár 1852: 455). The issue in this case is a mythical Slavic variant of sunken Atlantis, which appeared in numerous connections in German Pre-Romanticism/Romanticism in the 18th and 19th centuries.

The story of the Prillwitz idols is closely linked with the scholarly work of the historian and Evangelical pastor Andreas Gottlieb Masch (1724-1807), who wrote them up and published them (MASCH-Woge 1771). Over time, more than sixty bronze sculptures came to light from land next to the Tollensesee held by a Neubrandenburg goldsmith family after a local physician visiting the house of the Sponholz family noticed the first of the artefacts to emerge. The entire assemblage was purchased by Superintendent Andreas Masch on behalf of Duke Charles of Mecklenburg, who made it the most significant element in his collection. Throughout his life, Masch argued for the authenticity of the idols and for their Slavic character; according to him, they came from the temple at Rethra, a mythical, sunken town belonging to the Obodrite tribe.

The role of the Prillwitz idols in German culture is dealt with here at such length only to indicate hypotheses on the part of researchers that were later subjected to investigation. One of the most important elements in these was that the German cultural canon, which in the second half of the 18th century was still fluid, showed a gap which contemporaries wished to fill with the lost culture of the earlier, but by then assimilated, Slavic inhabitants of the country. From this point of view, the approach of the French and the English to Celtic culture, or the facing up of newly-minted American culture to the Indian past, may offer analogies. It was no coincidence that, having moved to the United States of America, Talvi (Therese Albertine Luise von Jakob) - the only significant female figure in the field of Slavic studies in Europe during the 19th century - began to research the culture of the American Indians (PRIBIČ 1986). Here, just two elements from the idols' reception among the Czechs are selected. The first is linked to Josef Dobrovský, who was not suspicious in this matter, and who gave news of the figurines in his book A History of the Language and Literature of the Czechs (DoBRowsKy 1792: 31). On the 
basis of this publication by Dobrovský, Masch was assigned a place in Kollár's Slavic Heaven, in sonnet 462 presenting Slavic antiquities, which afforded Kollár the opportunity to take the above data from Dobrovský. Probably, Kollár did not draw on Masch's book. Had he done so, he would probably have mentioned the copper engravings in the book that depict some of the sculptures, and would in all likelihood have touched upon the 'Rethra' inscription legible on a number of the bronze figurines (MASCH-WOGE 1771, figs. 2, 3, 4, 8, 13).

At bottom, then, the Prillwitz idols seemed to be objective evidence for the revival, through German mediation, of an early medieval pagan Slavic myth which in the decades of the era of national awakening fed the legend of pagan Slavic culture's high degree of material and spiritual development. Furthermore, Central European Slavic cultures embarking on the path to modernization were given this theme ready-made and free: it arrived from precisely that cultural territory against whose expansion they were most obliged to defend in these decades. The myth of the Prillwitz idols was demolished by the same German scholarship that had created it one century earlier. The fake character of the idols was proved beyond all doubt by the Mecklenburg antiquarian and archivist Friedrich Lisch (1801$1883)$. In this way, the case achieved notoriety as one of the greatest archaeological hoaxes of the 18th century (LINNEBACH 2011, Vоß 2005). ${ }^{6}$

\subsection{The Queen's Court and Green Mountain manuscripts}

The Queen's Court and Green Mountain manuscripts aroused strong emotions from the moment they entered the cultural mainstream, and struggles around their authenticity served to divide cultural paradigms and national ones in the course of the century. The debates concerning the authenticity of the manuscripts (BERKES 2003: 192-195) ${ }^{7}$ will not be outlined here; attention will instead be directed solely towards the manuscripts' incorporation into the Czech cultural canon. An important role in this process fell to Kollár, too, who ensured an eminent place for the Queen's Court Manuscript in sonnet 464 of The Daughter of Sláva. This was devoted to presenting the Slavic Library and its librarians (KolLÁr 1852: 464). According to the sonnet, visitors to the Slavic Heaven arrive at the Slavic Library, one of whose four especially valuable holdings is the work in question. In the explanation he gives of the sonnet, Kollár supplies the date of the manuscript's discovery, the name of its discoverer (Václav Hanka), and the name of the person who translated it into modern Czech (also Václav Hanka). He likewise included the names of those who put it into German and Russian, namely, those of Svoboda and Shishkov, respectively (KolláR 1832: 347).

\footnotetext{
${ }^{6}$ The idols were put on display by Neubrandenburg Museum in 2005, in an exhibition that opened there on 8 May that year.

${ }^{7}$ The specialized literature on the historical and philological background of the manuscripts runs to many volumes. Almost every 19th-century Czech poet, linguist, and philologist joined the discourse. The debate was closed reassuringly by T. G. Masaryk, who proved that the manuscripts were literary forgeries made by Václav Hanka.
} 
The Queen's Court Manuscript was found in 1817, in a tower room in the Queen's Court Church. Its discovery was such a revelation that Ferenc Toldy, a Hungarian literary historian of the day, gave an account of it in the Hungarian periodical Tudományos Gyüjtemény (see TOLDY 1830). ${ }^{8}$ This manuscript contained six heroic and historical cantos concerning, among other things, the battles of the Czechs against the Poles, the Saxons, and the Tatars, with eight further epic and lyric cantos forming an additional part of the manuscript. One year later, in even stranger circumstances, there came to light the Green Mountain Manuscript sent by a person unknown to Count František (or Franz Kolovrat). This work was allegedly made in the 10th century, and contained one canto whose main protagonist was Libuše. The case of the anonymous sender of the Green Mountain Manuscript was recorded by Kollár in sonnet 539 of The Daughter of Sláva. Contrary to expectations, however, retribution awaited the mysterious sender, on account of his 'furtive' self-concealment, which had caused the issue of the manuscripts' authenticity to come up. According to the explanation given for this sonnet, the discoverer of the Green Mountain Manuscript had wanted to protect the manuscript from the Germans on the one hand, and wished to protect his livelihood as someone in the employ of a Germanophile on the other (Kollár 1832: 416). In any event, he was punished for his faint-heartedness by being nailed by his tongue to the gate to the Slavic Hell, to be released only when he disclosed his identity. Later on, light was shone on this: the anonymous sender was, allegedly, a farm official working in a castle going by the name of Green Mountain (Zelená hora) not far from Nepomuk.

Doubts regarding the authenticity of the Queen's Court and Green Mountain manuscripts were first expressed by the above-mentioned Josef Dobrovský but the renowned antiquarian's views on them were opposed by the younger, Romantic, generation. Only in the last third of the 19th century did philological research convincingly demonstrate the fake character of these artefacts. Although the authorship of the manuscripts has yet to be established with absolute certainty (since the forger or forgers never owned up), most scholars take the view that Václav Hanka and Josef Linda were behind their creation (DoBIÁŠ 2010). They were, of course, internal Slavic and Czech cultural products which served the aim of strengthening the meagre structure of Czech culture in the Middle Ages with texts of a type that related to the most important historical events of the early medieval period as regards the Czechs (COOPER-DoBIÁš 2012).

The manuscripts positioned Czech culture in relation to that of the Germans by presenting a Slavic equivalent of the Nibelungenlied, which was written around 1200 in Middle High German, and even a victor in the Czech-German antiquities contest (its discoverers dated the Green Mountain Manuscript to a time two centuries earlier than that of the Nibelungenlied).

\footnotetext{
${ }^{8}$ One of the first Hungarian accounts is from a diary kept by Ferenc Toldy of a journey he made to Prague in August 1829. He published the part relating to the manuscript under the title Old Czech Literature.
} 


\subsection{Derzhavin's poem God in Japanese and Chinese translation}

From a number of points of view, the case below is relatable to the first example examined, namely, the Poison Tree of Java. In both cases, forgery took place on the level of information, namely, through channels of communication between the Slavic and the Anglo-Saxon cultural worlds. News that the Emperor of Japan and the Emperor of China had both ordered Derzhavin's poem God to be translated into their respective languages, inscribed in gold letters on silk fabric, and hung in their respective palaces appeared in sonnet 437 of The Daughter of Sláva. The information came originally from an anthology of Russian poems translated into English by John Bowring (KOLLÁr 1832: 322, Bowring 1822: 3-9). ${ }^{9}$

Referring to Vasily Mihailovich Golovnin in a footnote appended to the English translation of Derzhavin's poem, the English editor states that the Far East rulers would have had held the poem in high esteem (Kollár 1832: 322). On the other hand, S. Nagayo has proved that the information in question was probably taken from the diary kept by Golovnin during his imprisonment in Japan between 1811 and 1813. Published in St. Petersburg in 1816, this work was extraordinarily popular in its time and was translated into many languages. In his diary written in Japan, Golovnin did indeed record the story of the translations, although it takes place at a lowlier level and features unnamed protagonists (NAGAYO 1989: 270). The authenticity of Kollár's claims is, then, highly questionable. This much seems certain: there is no evidence of any early 19th-century translation of Derzhavin's poem in either of these Far East cultures (NAGAYo 1989: 271).

The above assemblage of antiquities and forgeries of antiquities can be expanded at will, and our hope is that a Slavic and Central European catalogue for the decades around the turn of the 19th century can be put together that will go beyond the category of cultural historical curiosity and become an organic part of the cultural history of the era. These examples show that when he worked with antiquities and fake antiquities, playing the imposter and pecuniary advantage were very far from Kollár, i.e. when he took on and disseminated information connected with fakes, he did so in good faith. On the other hand, as a philologist, he became a prisoner of contemporary national canonical and emblematic structures, dying in Vienna in 1852 before the exposure of fake Slavic antiquities could begin.

\section{References}

Altieri 1983 = AltiERI Charles: An idea of a literary canon. Critical Inquiry 10 (1983): $37-60$.

BERKES 2003 = BeRKEs Tamás: A cseh eszmetörténet antinómiái. Budapest: Balassi, 2003. Bogoljubova 1958 = БоголюбовА В. Г. Еще раз об источниках «анчара». В кн.: Пушкин. Исследования и материаль. Т. 2. Москва-Ленинград, 1958. 310-323.

\footnotetext{
${ }^{9}$ Kollár reproduces the English text accurately. Bowring does not support his remark relating to Golovnin with bibliographical data.
} 
BOWRING 1822 = BowrIng John: Specimens of the Russian Poets with Preliminary Remarks and Biographical Notices. Boston: Cummings and Hilliard, 1822.

COOPER-DobiÁš 2012 = CoOPer David L., DobiÁš Dalibor: Padělky jako romantická forma autorství. Rukopisy královédvorský a zelenohorský ze srovnávací perspektivy. Česká literatura 60 (2012): 26-44.

DoBIÁŠ 2010 = DoBIÁŠ Dalibor: Rukopis královédvorský. Rukopis zelenohorský. Brno: Host, 2010.

DOBROWSKY 1792 = DOBROWSKY Joseph: Geschichte der böhmischen Sprache und Literatur. Prag: Johann Gottfried Salve, 1792.

EICHHORN 1800 = EICHHORN Johann Gottfried: Allgemeine Bibliothek der biblischen Litteratur 10. Leipzig: Weidman, 1800.

GORAK 1991 = GORAK Jan: The Making of the Modern Canon. Genesis and Crisis of a Literary Idea. London-Atlantic Highlands, NJ: Athlone, 1991.

GrosSER 1714 = GrosSER Samuel: Lausitzische Merckwürdirgkeiten Darinnen von Beydem Marggraffthümern in fünff unterschiedenen Theilen von den wichtigsten Geschichten. Leipzig-Budissin: David Richter, 1714.

GustafsON $1960=$ GustafsOn Richard F. The Upas Tree. Pushkin and Erasmus Darwin. PMLA 75 (1960): 101-109.

HAWRYLUK 2009 = HAWRYLUK Vladimir: Evangéliaire slave de Reims dit Texte du Sacre. Paris: Editions Beaurepaire, 2009.

Kollár 1824 = Kollár Jan: Sláwy dcera we třech zpěwjch od Jana Kollára. Druhé wydánj. W Budjně: w Králowské universitické tiskárně, 1824.

Kollár 1832 = Kollár Jan: Wýklad čili Přjmětky a Wyswětlivky ku Sláwy Dceře. S obrazy, s mappau a s Přjdawkem drobněgšjch básnj rozličného obsahu. W Pešti: tiskem Trattnera a Károliho, 1832.

KÖRNER 1766 = KÖRNER George M. Philologisch-kritische Abhandlung von der Wendischen Sprache und ihrem Nutzen in der Wissenschaften. Leipzig: Johann Gabriel Büschel, 1766.

Legis 1829 = Legis Gustav Thormod: Die Runen und ihre Denkmäler. Leipzig: Johann Ambrosius Barth, 1829.

LINNEBACH 2011 = LINNEBACH Andrea: In den „Sümpfen der Hypothesen“ - Wissensvermittlung auf Irrwegen. Die Prillwitzer Idole und die landesarchäologische Forschung in der Aufklärungszeit: Andreas Gardt-Mireille Schnyder-Jürgen Wolf, Buchkultur und Wissensvermittlung in Mittelalter und Früher Neuzeit. Berlin-Boston: De Gruyter, 2011. 293-310.

Masch-Woge 1771 = Masch Andreas Gottlieb, Woge Daniel: Die gottesdienstlichen Alterthümer der Obotriten aus dem Tempel zu Rhetra am Tollenzer-See. Berlin: Carl Friedrich Rellstab, 1771.

МАтTHÄI 1721 = MAтTHÄI Georg: Wendische Grammatica . Budissin: David Richter, 1721.

NAGAyo 1989 = NAGAYo Susumo: Japonské motívy v poéme Slávy dcera Jána Kollára. Slovenská literatúra 36 (1989): 264-272.

PACNEROVÁ 1996 = PACNEROVÁ Ludmila: Česká varianta charvátské hranaté hlaholice. Slovo 44-46 (1994-1996). Zagreb, 1996. 45-62.

Praz 1963 = Praz Mario: Liebe, Tod und Teufel. Die schwarze Romantik. München: Deutscher Taschenbuch Verlag, 1963.

PRIBIČ 1986 = PRIBIČ Nikola R. Talvjs Beschäftigung mit den Sprachen und Bräuchen der nordamerikanischen Indianer. Festschrift für Wolfgang Gesemann. München: Hieronymus, 1986. 275-287. 
RADNÓTI 1995 = RADNÓTI Sándor: Hamisitás. Budapest: Magvető, 1995.

SCHLÖZER 1802 = SCHLÖZER August Ludwig: Russische Annalen in ihrer slavonischen Grundsprach verglichen übersetzt, und erklärt von August Ludwig Schlözer D. Hofrath, Professor in Göttingen. Theil 1. Allgemeine Einleitung in die alte Russische Geschichte und in die Nordische Geschichte überhaupt. Göttingen: Heinrich Dieterich, 1802.

SzILÁGYi 2005 = SzILÁGYI János György: Szirénzene. Okortudományi tanulmányok. Budapest: Osiris, 2005.

TOLDY 1830 = ToLDY Ferenc: Ó-cseh literatúra. Tudományos Gyüjtemény 1830/6: 117-124. Vољ 2005 = VОß Rolf: Die Schein-Heiligen von Prillwitz. Regionalmuseum Neubrandenburg zeigt spektakuläre Fälschungen aus dem 18. Jahrhundert. Das Museumsmagazin, 2005. 34-35.

Wachtel 2011 = Wachtel Michael: A Commentary to Pushkin's Lyric Poetry, 1826-1836. Madison: University of Wisconsin Press, 2011.

\section{RÓBERT KISS SZEMÁN \\ Department of Slavic Studies, Eötvös Loránd University (Budapest)}

\section{Slavic Antiquities and Forgeries as Means for the Shaping of Canons}

The study deals with the role of Slavic antiquities in the age of national revivals and with the forging of such antiquities. It discusses the subject of Slavic antiquities and forgeries in Central Europe, bringing in the cultural context of Western Europe as well.

'Antiquity' is understood to mean a kind of medium that conveyed textual or visual information. The collecting of antiquities became fashionable during the first decades of the 19th century and led to the need for antiquities to be described and categorized. In turn, antiquities served as corpuses for the shaping of modern national cultural canons. It contends that these artefacts, authentic and forged alike, played an important role in moulding the cultural canons of the Slavic nations in Central Europe.

An antiquity's canonical value stemmed from its age most of all and an antiquity needed to be linked as specifically as possible to the history and culture of a given nation. The worth of an antiquity was further boosted when it could be connected with historical personages of great significance. Finally, the more mysterious the history of an antiquity, the greater the degree of speculation permissible in regard to interpretations of it.

A forged antiquity is basically an objectification informed by the forger's thinking and imagination. A forgery bears not just marks characteristic of past times but also marks of the forger and those of the time in which the forgery was made. It is something which calls an entire system into question, thereby causing bewilderment. From this perplexity, only one phenomenon can derive benefit, namely, the national culture. Important among the motives for the forging of Slavic antiquities was the circumstance that framers of canons felt that the structures of their national cultures were incomplete. Researching the reasons for the forging, the study points out structural gaps in the canons in Central Europe as well as traumas stemming from forgeries. Using four examples taken from Kollár's oeuvre (the Poison Tree of Java, the Slavic idols of Prillwitz, the Queen's Court and Green Mountain manuscripts and Derzhavin's poem God in Japanese and Chinese translation) it presents the most common motives behind Slavic forgeries along with the kinds of fake most frequently encountered; it also shows the processes by which forgeries were exposed for what they were. 
These examples show that when Kollár worked with antiquities and fake antiquities, playing the imposter and pecuniary advantage were very far from him. On the other hand, as a philologist he became a prisoner of contemporary national canonical and emblematic structures.

Keywords: Slavic antiquities, forgery, cultural canons, 19th-century Czech and Slovak literature, national revivals, the Poison Tree of Java, the Slavic idols of Prillwitz, the Queen's Court and Green Mountain manuscripts, Derzhavin's poem God

Open Access. This is an open-access article distributed under the terms of the Creative Commons Attribution 4.0 International License (https://creativecommons.org/licenses/ by/4.0), which permits unrestricted use, distribution, and reproduction in any medium, provided the original author and source are credited, a link to the CC License is provided, and changes - if any - are indicated. (SID_1) 